\title{
Sensory characteristics and tenderness of meat from Ankole bulls: Influence of crossbreeding and feeding system
}

\author{
K. Kamatara ${ }^{1}$, D. Mpairwe ${ }^{1 \#}$, M. Christensen ${ }^{2}$, D. Mutetikka ${ }^{1}$ \& J. Madsen ${ }^{3}$ \\ ${ }^{1}$ Department of Agricultural Production, College of Agricultural and Environmental Sciences, Makerere University P. \\ O. Box 7062 Kampala, Uganda. ${ }^{2}$ Department of Food Science, University of Copenhagen, Frederiksberg C, Denmark. \\ ${ }^{3}$ Department of Large Animal Sciences, University of Copenhagen, Frederiksberg C, Denmark.
}

(Received 22 June 2012; Accepted 12 August 2013; First published online 5 September 2013)

Copyright resides with the authors in terms of the Creative Commons Attribution 2.5 South African Licence. See: http://creativecommons.org/licenses/by/2.5/za/

Condition of use: The user may copy, distribute, transmit and adapt the work, but must recognise the authors and the South African Journal of Animal Science

\begin{abstract}
Eating-quality attributes of meat from Ankole cattle and their Friesian and Boran crossbreds finished in different feeding systems were evaluated. Seventy two 8-month-old bulls (24 each of pure Ankole (A), Ankole x Boran (B) and Ankole x Friesian (F) (191 $\pm 9.6 \mathrm{~kg}$ average weight) were allotted to three feeding systems in a completely randomized design with a $3 \times 3$ factorial treatment, and were slaughtered after 120 days. The longissimus dorsi muscle was excised from the carcasses and divided into five samples for sensory and shear force analysis. Samples aged 2, 7, 14 and 21days were subjected to the Warner Braztler shear force (WBSF) machine for textural tenderness determination. Steaks from Ankole and Friesian crossbreds attained WBSF values below $55 \mathrm{~N}$ within 7 days of post mortem storage, whereas Boran crossbreds attained a similar level of tenderness at 14 days. Steaks from Ankole and Friesian crossbreds were rated more tender, juicy and acceptable than Boran crossbreds by panelists. Steaks from grazed bulls were rated less tender, juicy and palatable than steaks from supplemented and feedlot finished bulls. It was concluded that when grazed and supplemented or finished in a feedlot and meat aged for 7 days, Ankole bulls produce tender meat of an as high eating-quality as their Ankole x Friesian crossbreds.
\end{abstract}

Keywords: Ankole cattle, crossbreds, feeding system, sensory scores, meat tenderness

${ }^{\#}$ Corresponding author: dmpairwe@agric.mak.ac.ug

\section{Introduction}

Uganda's beef industry is mainly supported by indigenous cattle raised under the pastoral systems with the Ankole cattle being the main breed of beef (UIA, 2010). Under the pastoral system, cattle herds are raised on unimproved natural pastures which have a fluctuating forage supply pattern between dry and wet seasons. Coupled with poor genetic potential of indigenous animals under pastoral systems, they have slow growth rates, attain market weight after 4 - 5 years (Mpairwe et al., 2003) and are considered inferior without any foreseeable room for improvement (Ndumu et al., 2008). To increase productivity and quality of meat from Ankole cattle, cross-breeding with high-yielding exotic breeds, especially Friesians and Boran, is on the increase which puts Ankole cattle at risk of extinction. A study conducted by Katongole (2003) revealed that if presented with appropriate finishing management, Ankole cattle had an inherent potential to produce beef of comparable eating quality to that of their crossbreds. The present study was therefore conducted to test whether the Ankole cattle and its Boran and Friesian crossbreds can give beef of similar eating-quality under supplementation and feedlot finishing. The study was also conducted to test the influence of post mortem storage on textural tenderness on beef from the three genotypes. 


\section{Materials and Methods}

Seventy two 8-month-old bulls (24 each of pure Ankole (A), Ankole x Boran (B) and Ankole x Friesian (F) (191 $\pm 9.6 \mathrm{~kg}$ average weight) were allotted to three feeding systems in a completely randomized design with a $3 \times 3$ factorial treatment. Feeding systems comprised of sole grazing (GZ), grazing and supplemented with concentrate (GS) and feedlot (FL). The chemical composition of feeds used is presented in (Table 1), while data for concentrate composition and weight gains are presented in Asizua et al. (2009). After 120 days of feeding, bulls were transported to the Uganda Meat Industries abattoir and left for 18 hours to rest in the lairage before they were slaughtered without stunning.

Table 1 Chemical composition of ingredients in experimental diets with standard deviation

\begin{tabular}{lccc}
\hline & Concentrate & Maize Stover & Pasture \\
\hline & $905 \pm 4.4$ & $889 \pm 22.5$ & $879 \pm 9.4$ \\
Dry matter (g/kg) & $17.4 \pm 0.6$ & $15.2 \pm 1.0$ & $15.3 \pm 0.9$ \\
Gross energy (MJ/kg DM) & $150.8 \pm 9.9$ & $53 \pm 6.7$ & $90 \pm 11.9$ \\
Crude protein (g/kg DM) & $285.5 \pm 13.8$ & $692.6 \pm 34.2$ & $558.1 \pm 22.7$ \\
Neutral detergent fibre (g/kg DM) & $76 \pm 5.0$ & $405.6 \pm 18.9$ & $346.6 \pm 16.1$ \\
Acid detergent fibre (g/kg DM) & $26.4 \pm 0.7$ & $63.2 \pm 5.1$ & $59.2 \pm 5.4$ \\
Acid detergent lignin (g/kg DM) & $94.2 \pm 3.8$ & $4.2 \pm 0.6$ & $9.8 \pm 1.6$ \\
Ether extract (g/kg DM) & $52.2 \pm 2.2$ & $103.5 \pm 6.1$ & $80.2 \pm 4.7$ \\
Ash (g/kg DM) & $1.5 \pm 0.2$ & $0.3 \pm 0.05$ & $4.5 \pm 1.2$ \\
Calcium (g/kg DM) & $4.2 \pm 0.4$ & $7.8 \pm 0.9$ & $8.2 \pm 1.1$ \\
Phosphorus (g/kg DM) & & & \\
\hline
\end{tabular}

At $48 \mathrm{~h}$ post mortem, the longisimuss dorsi muscle on the left carcass side was excised and divided into five pieces of $5 \mathrm{~cm}$ in fibre direction for sensory and Warner Braztler shear force (WBSF) analysis. Samples of muscle for sensory analyses and for WBSF (day 2) were immediately frozen at $-18{ }^{\circ} \mathrm{C}$, while other samples were kept for 7, 14 and 21 days at $+4{ }^{\circ} \mathrm{C}$ in a refrigerator and then frozen at the end of each ageing period. Sensory attributes were determined using a nine-member trained panel, according to the American Meat Science Association (AMSA, 1978) guidelines. Samples aged at 2, 7, 14 and 21days were thawed at $+4{ }^{\circ} \mathrm{C}$ for 24 hours and later boiled in a water bath (Fischer Scientific) set at $75{ }^{\circ} \mathrm{C}$ for 60 minutes. After the boiled samples were cooled in running tap water, five rectangular blocks of $1 \mathrm{~cm} \times 1 \mathrm{~cm} \times 5 \mathrm{~cm}$ were cut from each sample in fibre direction. Warner shear blade, attached to Zwick/Roell (Z2.5, German) instrument set with $1 \mathrm{KN}$ load cell at crosshead speed of $50 \mathrm{~mm} / \mathrm{min}$ was used to determine the required shear force $\left(\mathrm{N} / \mathrm{cm}^{2}\right)$ to shear through a muscle. The average shear force for 5 cubes sheared twice was considered as the peak force for each sample. The data were analysed using GLM procedure of SAS statistical package (SAS, 2001). Analysis model included genotype, feeding system and the two-way interaction between genotype and feeding system as main effects. When means were significantly different at $P<0.05$, they were separated by Least Significant Different test.

\section{Results and Discussion}

Across all feeding systems, steaks from Ankole and Friesian crossbreds were rated more $(P<0.05)$ tender and juicy than Boran crossbreds (Table 2), which could possibly be due to the excitable nature of the Boran crossbreds. Animals of an excitable nature release high levels of catecholamines pre-slaughter which results in glycogen depletion leading to high ultimate $\mathrm{pH}$ and subsequently tough meat (Neath et al., 2007; Muchenje et al., 2009). Steaks from feedlot and supplemented bulls were rated more tender than grazed bulls, probably because of higher intramuscular fat which increases tenderness through increased sensation (Fiems et al., 2000). 
Across all genotypes, steaks from feedlot and supplemented bulls had lower $(P<0.01)$ WBSF values lower than steaks from grazed bulls (Table 3), which was attributed to higher weight gains in supplemented than grazed bulls (Asizua et al., 2009). Shear force values in Ankole bulls differed $(P<0.01)$ across systems, steaks from supplemented bulls required less ageing time (7 days) to attain a WBSF value of 55N than grazed and feedlot bulls which took 14 days to acquire the same level of tenderness. In general, meat with WBSF values greater than 55N is considered tough by sensory panelists in beef (Shackelford et al., 1995). Hence a modest amount of concentrate fed to rangeland grazed cattle can be used to improve meat tenderness; likewise ageing meat up to 14 days makes beef tender. Feedlot Boran crossbreds attained a WBSF value lower than $55 \mathrm{~N}$ by 7 days of ageing, while steaks from grazed and supplemented bulls required ageing up to 14 days to attain a similar level. High WBSF values in grazed Boran crossbreds were attributed to a relatively high excitable nature compared to their feedlot counterparts, which were already used to people by the time of slaughter.

Table 2 Least square means of sensory attributes of roasted samples of meat of Ankole cattle and their crossbreds finished on three dietary treatments

\begin{tabular}{|c|c|c|c|c|c|c|c|c|c|c|c|c|c|}
\hline \multirow{2}{*}{ Attribute } & \multicolumn{3}{|c|}{ A } & \multicolumn{3}{|c|}{ AXB } & \multicolumn{3}{|c|}{ AXF } & \multirow[b]{2}{*}{ SEM } & \multicolumn{3}{|c|}{ Significance } \\
\hline & GZ & GZS & FL & GZ & GZS & FL & GZ & GZS & FL & & Gen & $\mathrm{T}$ & GenXT \\
\hline Tenderness & $5.0^{\mathrm{a}}$ & $6.2^{\mathrm{b}}$ & $6.0^{\mathrm{b}}$ & $5.1^{\mathrm{a}}$ & $5.1^{\mathrm{a}}$ & $6.3^{\mathrm{b}}$ & $5.6^{c}$ & $6.3^{\mathrm{b}}$ & $6.0^{\mathrm{b}}$ & 0.21 & $*$ & $*$ & $*$ \\
\hline Juiciness & $4.5^{\mathrm{a}}$ & $6.6^{\mathrm{b}}$ & $6.4^{\mathrm{b}}$ & $4.8^{\mathrm{a}}$ & $5.9^{c}$ & $6.7^{\mathrm{b}}$ & $5.8^{\mathrm{c}}$ & $6.5^{\mathrm{b}}$ & $6.4^{\mathrm{b}}$ & 0.20 & $*$ & $*$ & $*$ \\
\hline Flavour & $5.1^{\mathrm{a}}$ & $6.3^{\mathrm{b}}$ & $6.5^{\mathrm{b}}$ & $5.0^{\mathrm{a}}$ & $6.2^{\mathrm{b}}$ & $6.4^{\mathrm{b}}$ & $5.2^{\mathrm{a}}$ & $6.3^{\mathrm{b}}$ & $6.5^{\mathrm{b}}$ & 0.17 & $*$ & $*$ & $*$ \\
\hline Palatability & $5.2^{\mathrm{a}}$ & $6.0^{\mathrm{b}}$ & $6.8^{\mathrm{c}}$ & $5.0^{\mathrm{a}}$ & $6.0^{\mathrm{b}}$ & $6.1^{\mathrm{b}}$ & $5.0^{\mathrm{a}}$ & $6.9^{c}$ & $6.1^{\mathrm{b}}$ & 0.13 & $*$ & $*$ & $*$ \\
\hline Acceptability & $5.5^{\mathrm{a}}$ & $6.2^{\mathrm{b}}$ & $6.8^{\mathrm{c}}$ & $4.5^{\mathrm{d}}$ & $6.3^{\mathrm{b}}$ & $6.9^{c}$ & $5.5^{\mathrm{a}}$ & $6.8^{\mathrm{c}}$ & $6.9^{c}$ & 0.2 & $*$ & $* *$ & $*$ \\
\hline
\end{tabular}

ns: not significant; ${ }^{* * *} P \leq 0.001,{ }^{* *} P \leq 0.01 ; * P \leq 0.05$; A: Ankole, AXB: AnkolexBoran; AXF: AnkolexFriesian.

GZ: grazing alone; GZS: grazing plus supplementation; FL: feedlot; Gen: genotype; T: dietary treatment;

GenXT: genotype x treatment interaction.

Table 3 Least square means of Warner-Bratzler shear force of Ankole cattle and their crossbreds finished on three dietary treatments

\begin{tabular}{|c|c|c|c|c|c|c|c|c|c|c|c|c|c|}
\hline \multirow{2}{*}{$\begin{array}{l}\text { Ageing } \\
\text { period/days }\end{array}$} & \multicolumn{3}{|c|}{ A } & \multicolumn{3}{|c|}{$\mathrm{AXB}$} & \multicolumn{3}{|c|}{ AXF } & \multicolumn{4}{|c|}{ Significance } \\
\hline & GZ & GZS & FL & GZ & GZS & FL & GZ & GZS & FL & SEM & Gen & $\mathrm{T}$ & GenXT \\
\hline 2 & $67.2^{\mathrm{a}}$ & $61.3^{\mathrm{b}}$ & $62.4^{\mathrm{a}}$ & $77.2^{\mathrm{c}}$ & $73.1^{\mathrm{c}}$ & $67.9^{\mathrm{a}}$ & $66.1^{\mathrm{a}}$ & $61.9^{\mathrm{b}}$ & $58.1^{\mathrm{b}}$ & 3.54 & * & * & $* *$ \\
\hline 7 & $60.7^{\mathrm{a}}$ & $54.6^{\mathrm{b}}$ & $58.2^{\mathrm{a}}$ & $62.5^{\mathrm{a}}$ & $61.5^{\mathrm{a}}$ & $50.8^{c}$ & $58.6^{\mathrm{a}}$ & $54.4^{\mathrm{b}}$ & $51.2^{\mathrm{bc}}$ & 2.41 & * & * & $* *$ \\
\hline 14 & $54.4^{\mathrm{a}}$ & $50.0^{\mathrm{b}}$ & $51.3^{\mathrm{b}}$ & $56.1^{\mathrm{a}}$ & $54.9^{\mathrm{a}}$ & $50.6^{\mathrm{b}}$ & $49.1^{\mathrm{b}}$ & $48.8^{\mathrm{bc}}$ & $47.4^{\mathrm{c}}$ & 2.0 & ns & * & $* *$ \\
\hline 21 & $47.7^{\mathrm{a}}$ & $42.8^{\mathrm{b}}$ & $43.3^{\mathrm{b}}$ & $46.6^{\mathrm{a}}$ & $46.5^{\mathrm{a}}$ & $45.6^{\mathrm{a}}$ & $42.2^{\mathrm{b}}$ & $43.3^{b}$ & $43.4^{\mathrm{b}}$ & 1.62 & ns & * & * \\
\hline
\end{tabular}

ns: not significant; ${ }^{* *} P \leq 0.001,{ }^{* *} P \leq 0.01 ; * P \leq 0.05$; A: Ankole, AXB: AnkolexBoran; AXF: AnkolexFriesian.

GZ: grazing alone; GZS: grazing plus supplementation; FL: feedlot; Gen: genotype; T: dietary treatment;

GenXT: genotype x treatment interaction.

\section{Conclusion}

Findings of this study demonstrated that modification of the traditional feeding system through supplementation enables the indigenous Ankole breed to produce beef of high quality without necessarily crossbreeding. It was also recorded in this study that Boran crossbreds produce less tender meat than Ankole and Ankole X Friesian crossbreds. Where bulls were slaughtered directly from rangelands without any supplementation, beef should be aged up to 14 days to improve tenderness. 


\section{Acknowledgements}

The authors would like to thank the Danida Fellowship Centre for the financial support of the ENRECA project "Income Generation through Market access and improved Feed Utilization: Production of quality Beef and Goat Meat (IGMAFU-Meat” Project) and Carnegie of New York, which funded the study and paper presentation, respectively.

\section{References}

Albertì P. B., Ripoll, G., Goyache, F., Lahoz, F., Olleta, J.L., Panea, B. \& Sańudo, C., 2005. Carcass characterization of seven Spanish beef breeds slaughtered at two commercial weights. Meat Sci. 71. 514-521.

American Meat Science Association, 1978. Guidelines for cooking and sensory evaluation of meat. American Meat Science Association, Livestock and Meat Board, Chicago, I.L., USA.

Asizua, D., Mpairwe, D., Kabi, F., Mutetikka, D. \& Madsen, J., 2009. Growth and slaughter characteristics of Ankole cattle and its Boran and Friesian crossbreds. S. Afr. J. Anim. Sci. 39 (Suppl. 1), 81-85.

Fiems, L.O., De Campeneere, S., De Smet, S., Van de Voorde, G., Vanacker, J.M. \& Boucque, C.V., 2000. Relationship between fat deposits in carcasses of beef bulls and effect of meat colour and tenderness. Meat Sci., 56, 41-47.

Katongole, B.C., 2003. Nutritional effects on growth and carcass characteristics of indigenous cattle bulls (Ankole and Nganda) and Ankole x Friesian crossbreeds. Thesis submitted for the award of Master of Science in Animal science, Faculty of Agriculture, Makerere University, Kampala, Uganda.

Mpairwe, D.R., Katongole, C., Bareeba, F.B., Mukasa-Mugerwa, E. \& Ebong, C., 2003. Effect of plane of nutrition on growth performance and carcass characteristics of growing Ankole, N'ganda and crossbred (Friesian X Ankole). Proceedings of the $30^{\text {th }}$ Scientific Conference of Tanzania Society of Animal Production (TSAP), 4 H Centre-Tanga, October $28^{\text {th }}-30^{\text {th }}$. pp. 179-199.

Muchenje, V., Dzama, K., Chimonyo, M., Strydom, P.E. \& Raats, J.G., 2009. Relationship between preslaughter stress responsiveness and beef quality in three cattle breeds. Meat Sci. 81, 653-657.

Ndumu, D.B., Baumung, R., Wurzinger, M., Drucker, A.G., Okello, D. \& Semambo, D., 2008. Performance and fitness traits versus phenotypic appearance in the African Ankole Longhorn cattle: A novel approach to identify selection criteria for indigenous breeds. Livest. Sci. 133, 234-242.

Neath, K.E., Del Barrio, A.N., Lapitan, R.M., Herrera, J.R.V., Cruz, L.C., Fujihara, T., Muroya, S., Chikuni, K., Hirabayashi, M. \& Kanai, Y., 2007. Difference in tenderness and $\mathrm{pH}$ decline between water buffalo meat and beef during postmortem ageing. Meat Sci. 75, 499-505.

SAS, 2003. Statistical Analysis Systems user's guide: ( $4^{\text {th }}$ ed.). SAS Institute Inc, Cary, N.C., USA.

Shackelford, S.D., Wheeler, T.L. \& Koohmaraie, M., 1995. Relationship between shear force and trained sensory panel tenderness ratings of 10 major muscles from Bos indicus and Bos taurus cattle. J. Anim. Sci. 73, 3333-3340.

Uganda Investment Authority, 2010. Investment Potentials in Beef Processing. Establishing a beef processing facility in Uganda. Twed Plaza, lot 22B, Lumumba Avenue, P.O. Box 7418 Kampala Uganda East Africa. 